\title{
WHY BOTHER WITH ELECTIONS?
}

\author{
Adam Przeworski \\ Polity Press, Cambridge, 2018. \\ DOI: 10.20901/an.15.14
}

Adam Przeworski, svjetski znani i utjecajni američki politolog poljskog podrijetla, u svojoj najnovijoj knjizi Zašto se gnjaviti s izborima? nastoji obraniti demokraciju u vremenu u kojemu je vjera u nju temeljito poljuljana. Budući da je riječ o znanstveniku koji se cijeli svoj profesionalni život bavi uvjetima nastanka i opstanka demokratskih sustava, vrijedi prikazati i odvagnuti njegove glavne argumente.

Radovi Przeworskoga nezaobilazni su u suvremenoj politologiji, ponajprije na područjima političke ekonomije i demokratizacije. Najcitiranija mu je knjiga Democracy and the Market (1991), slijede Democracy and Development: Political Institutions and Well-being in the World 1950-1990 (2000), koju je napisao s M. Alvarezom, J. A. Cheibubom i F. Limongijem, te časopisni radovi "The Logic of Comparative Social Inquiry" (1970), napisan s H. Teuneom, i "Modernization: Theories and Facts" (1997), napisan s F. Limongijem.

Njegov je rad, nažalost, slabo prisutan na hrvatskome akademskom prostoru. Nijedna njegova knjiga nije objavljena u Hrvatskoj, a samo je "Logika poredbenog društvenog istraživanja", važan rad napisan s H. Teuneom, preveden na hrvatski i objavljen u zborniku Uvod u komparativnu historiju (2004) koji je uredio Drago Roksandić. Pretraga na hrvatskome akademskom portalu Hrčak upućuje na četiri nalaza: prijevod njegova i Salomonova rada o umijeću pisanja projektnih prijedloga (1994) te tri navo- da u radovima objavljenima u Političkoj misli: prvi je prikaz knjige Przeworskoga koji je napisao T. Kursar (1994), drugi je analiza tranzicije u istočnoj Europi N. Zakošeka (1995), a treći je rasprava o tranzitologiji D. Jovića (2010). Sva trojica autora referiraju se na Democracy and the Market, pri čemu Kursar iz knjige iščitava "neopravdan socijalistički radikalizam", Zakošek autora prikazuje kao "liberalnoga američkog politologa", a Jović ga označava kao "bivšega marksista". Uzevši u obzir slabu domaću recepciju radova Przeworskoga, prije prikaza teza iz njegove nove knjige, ukratko ću podsjetiti na njegove najvažnije znanstvene doprinose.

Tijekom karijere Przeworski je sudjelovao u nekoliko važnih međunarodnih istraživačkih projekata. Prvi je bio "Rujanska skupina", više istraživača koje su okupili kanadski filozof G. A. Cohen i norveški politolog J. Elster u Londonu 1979. kako bi pokušali revitalizirati marksistička istraživanja. Skupina se sastajala petnaestak godina, a u njoj su sudjelovali J. Roemer, R. Brenner, Ph. Van Parijs, S. Bowles, E. O. Wright i drugi. Plod je njihova rada zbornik eseja Analitički marksizam (1986) pa su pod imenom "analitički marksisti" postali i šire prepoznatljivi. Wright (1994) navodi da je skupina bila politički heterogena, okupivši krajnje ljevičare, zelene i lijeve liberale, te da je i o teorijskim pojmovima bilo mnogo nesuglasja njezinih članova. Zajednički pothvat činilo je osuvremenjivanje marksističke analize osla- 
njanjem na metodološki individualizam i teoriju igara. Riječ je o neobičnome teorijskom sučelju budući da je teorija racionalnog izbora proizašla iz primjene neoklasične ekonomije na političko ponašanje te da se vezuje za uspon neoliberalne desne misli (Wood 1989). Przeworski je u tome razdoblju objavio niz utjecajnih radova. U suradnji s $\mathrm{M}$. Wallersteinom objavio je radove u kojima se nastojalo objasniti zašto širenjem prava glasa demokracije nisu dokinule kapitalističke poretke (1982a, 1982b) te unaprijediti raspravu o strukturnoj ovisnosti države o kapitalu (1988).

Sljedeći veliki istraživački projekt bio je vezan za skupinu okupljenu oko G. O'Donnella, Ph. Schmittera i L. Whiteheada, a rezultirao je iznimno utjecajnim nizom publikacija o tranzicijama u demokraciju. I ta se skupina počela sastajati 1979. u Washingtonu. U razgovoru s G. Munckom (Munck i Snyder 2007), Przeworski ističe kako ga se na tim sastancima najviše dojmilo to što se u raspravama o tranziciji u demokraciju u Latinskoj Americi i Južnoj Europi nisu oslanjali na radove B. Moorea i S. M. Lipseta koji su u to doba bili obvezatna studijska literatura na sveučilištima. Pristupi Moorea i Lipseta analizi tranzicija u demokraciju činili su im se previše determinističkima. Kako su mislili da tranzicije nisu bile uzrokovane ni klasnom strukturom formiranom prije dva stoljeća ni razinom ekonomskog razvoja, bilo je potrebno analizirati strateške opcije s kojima su se suočile elite i objasniti okolnosti i odluke koje su donesene $u$ presudnim razdobljima tranzicije. "Tranzitologija" se tako pomaknula od strukturnih pristupa ka akterskim modelima, odnosno analizi strateškog ponašanja prorežimskih i opozicijskih elita. Radovi nastali iz toga istraživačkog programa, objavljeni u četiri knjige naslovljene Transitions from Authoritarian Rule (1986), presudno su utjecali na komparativne analize demokratizacije $\mathrm{u}$ sljedećih dvadesetak godina.

Treći istraživački projekt, koji se također pokazao iznimno utjecajnim, Przeworski je počeo devedesetih godina kada je broj demokracija u svijetu porastao dostatno da omogući statističke analize. Premda je prije kritizirao analize "povijesti bez ljudi", Przeworski (1997) se u toj fazi okrenuo k strukturnim analizama i "korelacijama bez ljudi" (Munck i Snyder 2007). Glavni je nalaz njegovih istraživanja iz te faze da razina ekonomskog razvoja objašnjava opstanak, ali ne i nastanak demokratskih poredaka. Taj je nalaz izazvao mnoge prijepore i suprotne analize. No Przeworski i danas ustrajava na stavu da su studije koje "dokazuju" povezanost ekonomskog razvoja i nastanka demokracija utemeljene na pogrešno specificiranima modelima, budući da izgledi za tranziciju u demokraciju ovise o prošlim događajima, a ne samo o trenutačnim pokazateljima. Kada se u modele unesu obilježja prijašnjih režima, nestaju statističke poveznice razine razvoja i demokratizacije. Drugim riječima, ako Przeworski ima pravo, ne treba očekivati da povećanjem razine razvoja porastu i izgledi da će zemlja postati demokracija.

No Przeworski je najpoznatiji prema svojoj minimalističkoj definiciji demokracije. U razgovoru s Munckom otkrio je inicijalne okolnosti u kojima je postao pobornikom definicije demokracije kao poretka u kojemu ljudi neće poubijati jedni druge, a neće ih ubiti ni njihove vlasti. Przeworski to određenje demokracije izvodi iz radova K. Poppera (1945) i N. Bobbija (1984). Svjedočeći iz prve ruke državnom udaru kojim je 1973. srušen čileanski predsjednik S. Allende, postalo mu je jasnim da svaki potez koji podriva demokraciju može uzrokovati masovno nasilje te da je stoga najviši cilj obrana demokracije. Prema mišljenju Przeworskom, sudbina 
Allendeove vlade bila je vrlo važna za ljevicu zato što su dotad mnogi na ljevici bili neodlučni u gledanjima na to jesu li socijalistički ciljevi važniji od poštovanja demokratskih institucija. Tijekom 1973. vodile su se eksplicitne rasprave o dvojbi koja je ljevicu mučila i između dvaju svjetskih ratova: treba li na prvo mjesto staviti socijalizam ili demokraciju? Przeworskome je izlaz iz te dvojbe bio potpuno jasan: put u socijalizam može biti onoliko brz koliko je masovna potpora izražena na izborima (2016).

U knjizi Zašto se gnjaviti s izborima? Przeworski želi obraniti demokraciju u vremenu njezine krize. Knjiga se sastoji od dvaju dijelova: "Kako funkcioniraju izbori" i "Što izbori mogu i ne mogu postići". Poznavatelji njegova djela brzo će utvrditi da se autor oslanja na argumente koje je razvio u prijašnjim radovima, s tim da su oni u ovoj knjizi "upregnuti" u eksplicitnu obranu demokracije kao poretka. Njegova je obrana demokracije, na određen način, kontradiktorna budući da želi ojačati vjeru u demokraciju tako da smanji očekivanja od nje. Kao što sam kaže u uvodu, izborni proces najčešće nas razočara - bilo da je riječ o ishodu izbora jer su pobijedili suparnički kandidati bilo da je riječ o ponašanju kandidata za koje smo glasovali nakon što preuzmu vlast. Bez obzira na to, na sljedećim izborima opet se nadamo da će naš kandidat pobijediti pa se naprestance izmjenjuju nada i razočaranje. Sport je, kaže Przeworski, najbliža analogija toj emocionalnoj klackalici u kojoj ustrajavamo u podršci svojemu timu bez obzira na uspone i padove.

Polazeći od temeljnoga uvida da ljudi od demokracije očekuju mnogo, u svojim analizama još od ranih osamdesetih godina do danas nastoji obraniti definiciju prema kojoj je demokracija poredak koji je sposoban procesuirati sukobe na miran način, koji unosi jedinstvenu mjeru neizvjesnosti u političke ishode $\mathrm{i}$ koji omogućava društvenim skupinama da sklope bitne kompromise. S obzirom na rasprave o demokraciji u hrvatskome javnom prostoru, čini se bitnim izdvojiti još dvije teme iz ove knjige: prva se odnosi na implikacije činjenice da se demokratski izbori provode u kapitalističkim ekonomijama, a drugi na raspravu o tome proizvodi li demokratski proces racionalna društvena rješenja.

Przeworski želi da osvijestimo činjenicu kako su politički procesi usidreni u društvo, ponajprije u njegovu vlasničku strukturu. Pritom se oslanja na svoje ranije radove u kojima je dokazivao strukturnu ovisnost vlasti o vlasnicima kapitala. Nadovezujući se na radove Poulantzasa (1973) i Lindbloma (1977), nastojao je dokazati kako je ovisnost države o vlasnicima kapitala neizbježna zato što vlasnici kapitala donose odluke o investiranju. Privatno vlasništvo nad proizvodnim resursima bitno ograničava ishode demokratskih procesa jer vlade, bilo lijeve bilo desne, jednako ovise o privatnim vlasnicima kapitala koji donose ključne odluke o investiranju i zapošljavanju.

Posljedično, vlade u demokratskim porecima ograničene su i u borbi protiv ekonomskih nejednakosti. No unutar te strukturne ovisnosti postoji značajan prostor za djelovanje, što dokazuju znatne razlike u razinama nejednakosti u pojedinim državama i vremenima. Da da bi se razumjele te varijacije, treba osvijestiti temeljnu dinamiku u kojoj je demokracija igra prema općima apstraktnim pravilima koja su jednaka za sve, a igraju igrači s vrlo različitim resursima. U kapitalističkim demokracijama novac transformira ekonomsku moć u političku te stoga "kapitalizam postavlja ograničenja odlukama koje možemo donijeti na izborima" (2018: 125). Iako je danas u Hrvatskoj opći stav o kapitalizmu vjerojatno više negativan nego pozitivan, ponajprije zbog proširenog stava 
o privatizaciji kao pljački koja je proizvela nezasluženo bogatu klasu, a ostale osiromašila, malo tko iz toga stava izvodi takve implikacije za funkcioniranje i mogući doseg demokratskih institucija.

Przeworski podsjeća na to da su inicijalni zagovornici predstavničke vladavine silno strahovali od širenja prava glasa. Ako se dade pravo glasa svima, pretpostavljali su, a većina je siromašna, ona će glasovati za oduzimanje privatne imovine vlasnicima. Stoga je temeljni problem tijekom povijesnog razvoja demokracije bio kako urediti predstavničku vladavinu da zaštiti bogate od siromašnih. Zaštita vlasništva glavna je os političkih sukoba već dva stoljeća te, iako su mnoge bitke dobivene, pobjede nisu ireverzibilne jer vlasnici kapitala imaju mnogo resursa koje koriste kako bi zaštitili svoje interese (2018: 30). Povijesno su se štitili neizabranima gornjim domovima, onemogućavanjem opozicije, pravom neizabranih tijela da blokiraju zakonodavne prijedloge i ograničavanjem prava glasa. Nadalje, klubovi, udruženja i sindikati tretirani su kao prijetnje poretku. Nakon što su srušene te prepreke, stvorene su nove, kao što je potvrđivanje zakona u neizabranima institucijama poput ustavnih sudova, prijenos ovlasti nad monetarnom politikom na neizabrana vodstva središnjih banaka, uvođenje mehanizama višestrukih većina koje štite status quo.

Przeworski posebno naglašava kako je zadaća ustavnih sudova zaštititi postojeća prava od privremenih većina. Taj se sukob obično opisuje kao "demokracija nasuprot vladavini prava". No "pravo ne može vladati, to mogu samo ljudi" (2018: 43). Pravo nije ni apstraktna sila ni logički stroj, nego ono što presude suci, jer i u parlamentima i na sudovima rade ljudi. Vladavina prava stoga znači da vlade koje su izabrale većine birača postupaju prema uputi sudova čak i onda kada je to protivno volji onih koji su ih izabrali. Osim toga, autor skreće pozornost na to kako se zagovor vladavine prava u javnom prostoru gotovo isključivo referira na građanska i politička prava, dok se vrlo rijetko spominje jedno od temeljnih prava - pravo na vlasništvo. Ustavni sudovi ovlašteni su poništiti odluke većine ako one narušavaju vlasnička prava, jer u ekonomski nejednakim društvima vlasnici čine manjinu kojoj je potrebna zaštita prava.

Druga važna tema koje se Przeworski dotiče jest pitanje racionalnosti ishoda demokratskoga procesa. U hrvatskome javnom prostoru često se poziva na stvaranje nacionalnoga konsenzusa te je bitno promisliti autoritarne implikacije takva pristupa. Političkim vođama odgovara mit o jedinstvu naroda, o tome kako svi dijelimo temeljne zajedničke vrijednosti te kako stoga u političkom životu treba tragati za konsenzusom. Mit o društvenom konsenzusu privlačan je zato što sadržava sliku racionalna i pravedna svijeta u kojemu najbolje rješenje postoji i moguće ga je postići. Pritom se ispušta iz vida da poziv na konsenzus sadržava neke vrlo negativne posljedice za demokracije.

Prvo, kada se u politici deklariranog konsenzusa pojave sukobi, oni se rješavaju isključivanjem "neprijatelja naroda", "stranih interesa" i "izdajnika". Drugim riječima, naličje poziva na jedinstvo čine stigmatizacija i progon Drugoga kojega mogu utjeloviti etničke, vjerske, seksualne i druge manjine, kao što svjedoči suvremeni prodor desnih stranaka u Europi i u nas. Politički sukob u kojemu je nacionalni konsenzus suprotstavljen izdajnicima koje treba eliminirati u tome je smislu potpuno nespojiv s demokratskim pluralizmom (Ost 2005). Drugo, mit o konsenzusu derogira status institucija i procedura. Kada bi interesi i vrijednosti bili sukladni, svatko bi želio živjeti pod istim zakonima. Przeworski (2018: 83-84) upo- 
zorava na to da onda "nije važno ni tko donosi odluke ni po kojim pravilima". Pojednostavnjeno, politici konsenzusa nisu potrebne demokratske institucije nego samo prosvijećeni vladari. Treće, ideja da postoji "ispravan" politički ishod pretvara kolektivni proces donošenja odluka u potragu za istinom. Pozivanje na opću volju ili javni interes sugerira da postoji stanje svijeta koje predstavlja najbolji ishod za sve, te da se umijeće vladanja sastoji u izboru najboljega puta do toga cilja. No različitima biračima "racionalni" su različiti ishodi izbora. Ako, primjerice, netko podupire pravo na pobačaj, njemu je racionalan ishod izbora zaštita reproduktivnih prava, ali ne treba pretpostaviti da to vrijedi za sve birače. Političke odluke jednima donose dobitak, a drugima gubitak. A ako je tako, jedini način na koji ishodi mogu biti racionalni u društvu heterogenih interesa i vrijednosti jest minimaliziranje nezadovoljstva ishodom. Volja većine način je da se to ostvari, budući da "odluka donesena voljom većine ima potporu neke većine, što nije slučaj ako odluke donosimo nekom drugom metodom" (2018: 90).

Utemeljenje racionalnosti u volji većine mora, prema tome, vrijediti unatoč tome što su ishodi nekad nepovoljni. Zaustavljanje širenja zaraznih bolesti javni je interes, ali većina birača može izabrati stranku koja se protivi obveznom cijepljenju. Iz perspektive javnog zdravstva, to je nesumnjivo loš ishod. No Przeworski nas potiče da se odlučimo: ili prihvaćamo ideju racionalnosti koja ne ovisi o volji većine, ili smatramo da volja većine definicijski predstavlja racionalan ishod. Nijedna od tih dviju opcija nije ugodna. Oslanjanje na proceduralna pravila ne jamči uvijek mudre ishode, ali donošenje odluka koje su suprotne volji većine znači preferiranje autoritarnih rješenja.

Danijela Dolenec 


\section{Literatura / Bibliography}

Bobbio, Norbert. 1984. The Future of Democracy. Minneapolis: University of Minnesota Press.

Jović, Dejan. 2010. Problems of Early Post-Communist Transition Theory: From Transition from to Transition to". Politička misao. (47) 5: 44-68.

Kursar, Tonči. 1994. Democracy and the Market. Politička misao. (31) 2: 193202.

Lindblom, Charles. 1977. Politics and Markets. New York: Basic Books.

Munck, Gerardo, Snyder, Richard. 2007. Passion, Craft, and Method in Comparative Politics. Baltimore: Johns Hopkins University Press.

O'Donnell, Guillermo, Schmitter, Phillipe, Whitehead, Laurence. 1986. Transitions from Authoritarian Rule. Baltimore: Johns Hopkins University Press.

Ost, David. 2005. Defeat of Solidarity. Anger and Politics in Postcommunist Europe. Ithaca: Cornell University Press.

Popper, Karl. 1945. The Open Society and its Enemies. London: Routledge \& Kegan Paul.

Poulantzas, Nicos. 1973. Political Power and Social Classes. London: New Left Books.

Przeworski, Adam, Wallerstein, Michael. 1982a. The structure of class conflict in democratic capitalist societies.
American Political Science Review. (76) 215-238.

Przeworski, Adam, Wallerstein, Michael. 1982b. Democratic Capitalism at the Crossroads. Democracy. (2) 52-68.

Przeworski, Adam, Wallerstein, Michael. 1988. Structural Dependence of the State on Capital. American Political Science Review. (82) 11-29.

Przeworski, Adam. 1991. Democracy and the Market. Political and Economic Reforms in Eastern Europe and Latin America. Cambridge: Cambridge University Press.

Przeworski, Adam. 2016. Democracy: A Never Ending Quest. Annual Review of Political Science. (19) 1: 1-12.

Przeworski, Adam. 2018. Why Bother With Elections? Cambridge: Polity Press.

Roksandić, Drago (ur.). 2004. Uvod u komparativnu historiju. Zagreb: Golden marketing.

Zakošek, Nenad. 1995. Ima li liberalizam budućnost $\mathrm{u}$ istočnoj Europi? Politička misao. (32) 1: 152-160.

Wood, Ellen Meiskins. 1989. Rational Choice Marxism: is The Game Worth the Candle? New Left Review. 177: 41-88.

Wright, Eric Olin. 1994. Interrogating Inequality: Essays on Class Analysis, Socialism and Marxism. London: Verso. 